\begin{tabular}{|c|c|c|}
\hline $\begin{array}{l}\text { PUCRS } \\
\text { PUA }\end{array}$ & $\begin{array}{l}\text { ESCOLA DE } \\
\text { HUMANIDADES }\end{array}$ & $\begin{array}{l}\text { Brazilian English Language Teaching Journal } \\
\text { BELT, Porto Alegre, v. 12, n. 1, p. 1-10, jan.-jun. } 2021 \\
\text { e-ISSN: } 2178-3640\end{array}$ \\
\hline def $\mathrm{http}: / / \mathrm{dx}$ & $\mathrm{org} / 10.15448 / 2178-3640.2021 .1 .41365$ & \\
\hline
\end{tabular}

SEÇÃO: ARTIGOS

\title{
Analysis on the use of politeness strategies in a scene of The Crown
}

Análise das estratégias de polidez usadas em uma cena de The Crown

\section{Ana Carolina Moura \\ Pompeu ${ }^{1}$}

orcid.org/0000-0002-9955-3515

ana.pompeu@edu.pucrs.br

Received on: 11/16/2021

Approved on: 07/22/2021

Published on: 12/15/2021.

\section{(c) (1)}

Artigo está licenciado sob forma de uma licença Creative Commons Atribuição 4.0 Internacional.

\begin{abstract}
This article aims to analyze the positive and negative politeness strategies speakers employ to avoid threatening the addresses' face in the series The Crown (2017) in season 02, episode 08 entitled Dear Mrs. Kennedy. The analysis is held in light of the Politeness Theory by Brown and Levinson (1987, first published in 1978). It could be observed through a qualitative analysis that when there is a relation of power between the speaker and the hearer, the speaker tends to use bald on record expressions, whereas when the speaker is the subordinate, he/she tends to utter negative strategies and hedges to mitigate the threat to the hearer's face. KEYWORDS: pragmatics, politeness theory, politeness strategies
\end{abstract}

RESUMO: Este artigo tem como objetivo analisar as estratégias de polidez positivas e negativas aplicadas pelos falantes a fim de evitar ameaçar a face do interlocutor na série The Crown, temporada 2, episódio 08 intitulada Dear Mrs. Kennedy. A análise é conduzida à luz da Teoria da Polidez de Brown e Levinson (1987, primeira publicação em 1978). Através da análise qualitativa da cena, foi possivel observar que quando há relação de poder entre o falante e o ouvinte, o falante tende a usar expressões diretas sem correção (bald on record), enquanto, quando o falante é subordinado, a tendência é usar estratégias negativas e recursos linguísticos de proteção (hedges) de modo a atenuar a ameaça feita à face do ouvinte.

PALAVRAS-CHAVE: pragmática, teoria da polidez, estratégias de polidez

\section{Introduction}

Linguists around the world have language as their object of study. They turn something that people use in everyday life into science. Pragmatics makes use of communication and people's interaction to observe and analyze their intentions, assumptions, purposes and goals. By choosing words, verbs and grammar in a conversation, speakers may commit themselves, may impose, suggest, criticize or even insult with or without the intention to. Hence, we can say that Pragmatics studies the relationship between linguistic forms and those who make use of them, that is, the speaker and the hearer.

The general behavior of humans in a society is the desire to be accepted and to belong to a group or community. The linguistic structure we choose

Pontifical Catholic University of Rio Grande do Sul (PUCRS), Porto Alegre, RS, Brazil. 
to communicate may include or exclude us from a group. That is why being aware of the pragmatics of a language is a key aspect in communication. When learning a foreign language, for example, the use of linguistic inaccurate grammar forms is easily "forgiven" by a hearer; however, the inappropriate use of pragmatic rules in a specific language might be offensive or rude depending on the culture.

In present days, the analysis of language from a Pragmatics perspective is crossing academic borders in everyday life. It has attracted considerable attention from professionals in different areas such as business. Companies have hired professionals specialized in linguistics as coaches to provide assistance to department managers and Human Resources members on how to approach their coworkers and clients. As already mentioned, the use of appropriate nouns, verbs and other linguistic structures may turn the communication of bad news into a message that does not sound so bad whether communicated in spoken or written form.

It is of note that the Politeness Theory provides specific apparatus to understand, explain and apply language in a range of situations which are current in life. One of politeness tenets are the maintenance of face, emphasizing solidarity and giving deference. Whether conscious or not, these tenets are applied in different periods of time, as can be seem in the dialogues uttered by the Royals. Considering the modern society we live in, it is essential to make use of the strategies posited by politeness theories in order to live in a community where people can express themselves politely. However, it seems that we are not so successful in this issue, as can be explained by what we see in the internet, but this is a topic for another paper.

Indeed, after watching the series The Crown, it became clear that the characters made use of politeness strategies in innumerous circumstances, especially when the addressee or the speaker was the Queen. All the formality that the Queen's position requires makes the cooperation between the participants in a conversation very difficult and complicated, particularly when the subject of the conversation was something that would not make her happy.

The scene chosen for this analysis deals with a very delicate issue that involves the Queen's reputation and even her physical appearance, uttered by someone she expressed appreciation for. The next sections of this paper present a description of politeness theory, as well as the strategies stemmed from it; it then describes methodology designed for the analysis and the discussion generated from it.

\section{Background}

There are four models of politeness theory in pragmatics literature: (i) the 'social norm' model, (ii) the 'conversational maxim' model by Leech (1983, 2003); (iii) the 'face-saving' model by Brown and Levinson (1978, 1987), and (iv) the 'conversational contract' model by Fraser (1990). However, according to Huang (2007) the 'face-saving' model by Brown and Levinson is the most influential and comprehensive among the four models.

Brown and Levinson's Politeness theory has been the topic of innumerous studies and criticism in the field of Pragmatics. A research conducted under the light of politeness has as a first step to address the concept of 'face'. According to Bargiela-Chiappini (2003), Ervin Goffman, a Canadian sociologist, inspired himself in Chinese sources to elaborate the concept of 'face'

as the positive social value a person effectively
claims for himself by the lines others assume he
has taken during a particular contact. Face is an
image of self delineated in terms of approved
social attributes - albeit an image that others
may share, as when a person makes a good
showing for his profession or religion by making
a good showing for himself. (Goffman, 1967, p. 5)

Some years later, Brown and Levinson (1987), following Goffman's definition of 'face', defined face as "something that is emotionally invested, and that can be lost, maintained, or enhanced, and must be constantly attended to in interaction" (Brown \& Levinson, 1987, p. 61). The authors assume that people tend to cooperate to maintain and protect 
each other's face in interaction, so that they do not take the risk to 'lose face', that is, to be embarassed or humiliated. On the contrary, people should make an effort to 'save face', to prevent each other from damaging one's reputation.

Brown \& Levinson assume that there is a model person "a competent adult member of a society who has an inclination to keep up his face" (Jansen \& Janssen, 2010, p. 2533). Furthermore, Brown \& Levinson (1987, p. 62) posit that every person has a face. The authors take the notion of face as an assumption and divide it into positive and negative face defining them as follows:

negative face: the want of every 'competent adult member' that his/her actions be unimpeded by others.

positive face: the want of every member that his wants be desirable to at least some others.

It is valid to say that the word 'negative' here, is not related to the adjective 'bad'; in fact, it is applied to make an opposition to 'positive'. The negative face is defined as the need to be free in our actions, in the sense of not having them imposed on by others, as well as the necessity to be respected and to be treated with deference, while the positive face refers to the need to be accepted as part of a society, to be liked by others. It is also important to say, according to Yule (1996), that politeness can be accomplished in situations of social distance and closeness. The author illustrates positive and negative face with the examples below:

a. Excuse me, Mr Buckingham, but can I talk to you for a minute?

b. Hey, Bucky, got a minute? (Yule, 1996, p. 60)

In (a), the speaker demonstrates he/she is aware of the distance between him/her and the addressee by employing in the utterance linguistic markers such as, excuse me, Mr., can I..., which convey respect and deference, whereas in (b) it is possible to note a closer relationship between the ones in the interaction, by the use of Hey to request attention, by the use of a nickname to address the hearer and the use of short grammatical structures.
Brown \& Levinson (1987) also assume that the positive and negative face of the model person are threatened when he/she takes part in the interaction. During interaction, individuals tend to save each other's face, that is, speaker (henceforth $\mathrm{S})$ and hearer (henceforth $\mathrm{H}$ ) tend to cooperate, showing mutual respect and maintain each other's face. Jansen \& Janssen (2010) use the following situation to exemplify how one's positive and negative face might be threatened:

\begin{abstract}
Model Person A requests Model Person B to lend him fifty dollars, A's own positive face is threatened because he finds himself belonging to the unpleasant category of people who bother other people. Furthermore, A has to admit to himself that he is somewhat dependent on $B$, which threatens his negative face. As for $B$, his negative face is threatened because he knows that A expects him to comply; therefore, he has to do something that A asks, which limits his personal wants. If $B$ refuses, he damages both his own positive face and that of requester $A$ because he denies the legitimacy, or at least the normality of the request. (Jansen \& Janssen. (2010, p. 2533)
\end{abstract}

In order to save the hearer's face in a situation in which the individial's image might be threatened, the speaker might use some strategies to show deference to the hearer's image. This is what Brown \& Levinson (1987) called negative politeness, while the positive politeness refers to the preservation of one's positive face. When a speaker chooses to reinforce the hearer's positive face he/she shows solidarity and emphasizes that both have the same goals or are part of the same group. According to the authors, "positive politeness can be associated with intimate language use, it can be used as a 'social accelerator', where S, in using positive politeness strategies, indicates that he/she wants to come closer to H" (Brown \& Levinson, 1987, p. 103).

When one disrespects positive and negative politeness, they are performing, what politeness theorists call, face threatening acts (FTAs). Considering that interaction is a cooperative action among those involved in a conversation, an FTA goes against this principle. In this case, the speaker is not concerned about preserving the hearer's self-image, threatening the positive 
face, nor cares about the space and freedom the other needs. According to Brown \& Levinson (1987. p.129) while positive politeness is free-range, negative politeness is specific and focused. It performs the function of minimizing the particular imposition that the FTA unavoidably causes.
So, to soften the threats that can be performed to one's face, Brown \& Levinson (1987) developed some strategies that speakers employ during interaction. There are five main strategies which one can choose to avoid or soften FTAs, as we can see in the image below from Brown \& Levinson (1987, p. 69):

Figure 1 - Brown and Levinson's (1987) strategies for performing FTAs.

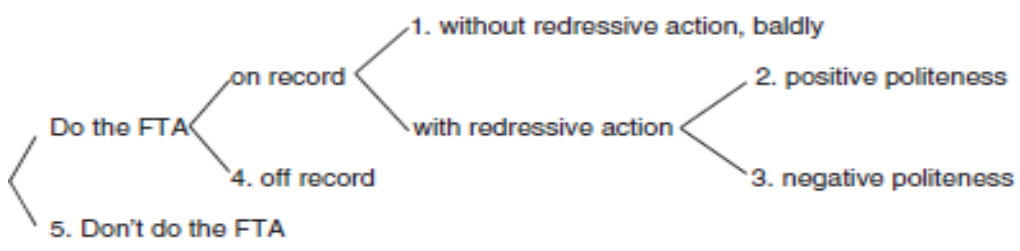

According to Brown and Levinson the reasonable action would be to avoid the FTAs. However, if the speaker finds him/herself in a situation in which there is mutual vulnerability of face, the speaker should employ these strategies to mitigate the threat. First, if the speaker chooses to say something on record, it means that he/she is direct in his/her words to express his/her needs; in this case the speaker can either, according to the schema above, say something on record, baldly, without redress or say something on record with redress and use positive politeness strategies (aiming at solidarity between partners in interaction and the creation of a friendly atmosphere) or use negative politeness strategies (giving deference to the hearer and the restoration of a negative face). Second, if the speaker chooses to say something off record, the speaker is indirect and provides hints, that is, the utterances one might say are not directly addressed to the hearer, the hearer can act as if the utterances were not heard. Finally, the last strategy means not saying anything, but acting out with the intention that your need will be recognized; here, one can give non-verbal hints, e.g. searching for something in the pocket, or bag.

Huang (2007, p. 118) summarizes the five superstrategies by Brown and Levinson's using the examples, as follows:
Situation: John, a student asks Mary, another student to lend him her lecture notes.

1. On record, without redress, baldly:

Lend me your lecture notes.

2. On record, with positive politeness redress: How about letting me have a look at your lecture notes?

3. On record, with negative politeness redress:

Could you please lend me your lecture notes?

4. Off record:

I didn't take any notes for the last lecture.

5. Don't perform the FTA:

[John silently looks at Mary's lecture notes.]

In bald on record speech can be performed by people from the same family or close friends, or for someone who decides to ignore the threat done by the FTA by uttering something unmitigated. The indirect speech (off record) is considered less threatening to one's face, while the on record speech, when acted in a conversation between unequal speakers, may be associated by situations in which the speaker knows he/she has power over the hearer. In order to mitigate the threat it is necessary to use positive or negative politeness strategies to diminish the damage to the hearer's face.

Brown \& Levinson (1987, p. 102) identified fifteen positive politeness strategies, as follows: 
TABLE 1 - Positive Politeness Strategies
(1) Notice, attend to $\mathrm{H}$
(2) Exaggerate attention to $\mathrm{H}$ (for example by giving compliments)
(3) Intensify interest to $\mathrm{H}$
(4) Use in-group identity markers
(5) Seek agreement
(6) Avoid disagreement
(7) Presuppose/raise/assert common ground
(8) Joke
(9) Assert or presuppose S's knowledge of and concern for H's wants
(10) Offer, promise
(11) Be optimistic
(12) Include both $\mathrm{S}$ and $\mathrm{H}$ in the activity
(13) Give or ask for reasons
(14) Assume or assert reciprocity
(15) Give gifts to $H$.

When a speaker needs to put into action negative politeness, he/she aims at showing deference and respect to the hearer and to his freedom of not being imposed on by others. Brown \& Levinson (1987, p.130) claim that the linguistic realization of negative politeness strategies typically involve conventionally indirectenesses, hedges on illocutionary force, apologies and the emphasis on the hearer's power.
The maintenance of negative face in negative politeness requires the achievement of distance between speaker and hearer, so for the linguistic realization of negative politeness Brown \& Levinson (1987, p. 131) listed ten strategies, as follows:

TABLE 2 - Negative Politeness Strategies
(1) Be conventionally indirect
(2) Question, hedge
(3) Be pessimistic
(4) Minimize the imposition
(5) Give deference
(6) Apologize
(7) Impersonalize S and H: avoid the pronouns 'I and 'you'
(8) State the FTA as a general rule
(9) Normalize
(10) Go on record as incurring a debt, or as not indebting $\mathrm{H}$.

The concept of 'hedge' is important because hedges are much used in negative politeness strategies. Brown \& Levinson (1987, p. 145) summarize the definition of hedges in the literature as a particle, a word, a phrase that modifies the degree of membership of predicate or a noun phrase in a set. Further, the use of hedge tends to avoid commitment between speakers; it is a method of disarming a threat.

The positive and negative politeness strategies will be applied as a methodological procedure to observe the utterances used in the series The Crown, aiming to show which strategies were used to protect the Queen's face when threatened by an unfortunate situation with the United States First Lady, Jackie Kennedy.

\section{Methodology}

The approach for studying The Crown's episode is a descriptive qualitative method. The data sources in this paper are the utterances taken from season 
2 episode 8, entitled "Dear Mrs. Kennedy". The focus of observation here, is a dialogue between Queen Elizabeth II and her friend, Patrick. The lines uttered by these two characters are analyzed under the light of Brown and Levinson's ([1978] 1987) politeness theory and the fifteen and ten strategies stemmed from it. In order to conduct the analysis, the transcript of the referred episode was downloaded from 8Flix website granted for entertainment, convenience and study.

In the episode, Queen Elizabeth is inspired by Jackie Kennedy and, against her government's wishes, she takes an unconventional approach to solve an issue in Ghana. During that time, she receives the American President and the first lady for a dinner. Some days after the reception at the Palace, the Queen is told that her newest friend had made some controversial comments about her and the Palace, so she decides to discover what kind of comments were uttered.

The series has been broadcasted in Brazil since 2020 on Netflix. The characters involved in the scene are: Queen Elizabeth II and Patrick, the Queen's friend, who attended the dinner in which the First Lady talked about the Queen behind her back. Princess Margaret, the Queen's sister, and Jackie Kennedy are not in the scene, but they are the ones responsible for the inconvenience.

\section{Analysis}

In this section the analysis of the scenes is presented. The major context of the scene is a gossip about Queen Elizabeth II uttered by the First Lady of the United States, Jackie Kennedy. In the scene Princess Margaret, the Queen's sister, tells Elizabeth that Patrick, their childhood friend, overheard some comments uttered by Jackie Kennedy about the Queen at a dinner he attended. The Queen wants to know what was said about her; for this reason she invites Patrick to the Palace. The excerpts that follow are the main lines uttered by the characters in question.

In line (1) the Queen asks Patrick, a question that may be considered very simple, in an ordinary conversation which, nevertheless, does not sound so simple to Patrick. In the Queen's first line despite her going on record, baldly, without redress, Patrick does not cooperate with her wants. The man chooses to use positive politeness strategy 6 , avoiding disagreement, since Patrick was confronted with the necessity to state an opinion. In this case, to talk about something he knows is going to damage the Queen's positive face, as well as disagreeing with her by saying he does not want to talk about that issue. So, he decides to be vague; this can be observed by the utterances in line 2 and 3, instead of which, nevertheless, threatening the Queen's face twice. Both characters know Patrick's answer is not true, but the hearer's face is saved by not having her request refused.

In spite of Patrick's vagueness in line (3), Elizabeth chooses to respond in a direct manner (line 4) performing an FTA on record, baldly without redress. According to Brown \& Levinson (1987, p. 69), a speaker is direct when he/she is not afraid of the hearer's retribution, in a circumstance in which "the danger to the hearer's face is very small". The Queen knows that being direct in this situation will not threat Patrick's face, such that he replies in line 5 using positive politeness strategy 5 , seeking agreement. By saying "the food's always good", allows Patrick to stress his agreement with the Queen and, therefore, corroborates with her opinion. Considering their close relationship, they both know the food at the Radziwills' is always good so much so that she confirms by uttering line 6 .

\section{ELIZABETH: So how was that? (1)}

PATRICK: Pleasant enough. Uneventful. Ilaughs nervously] (2)

PATRICK: You know how it is at the Radziwills'. (3)

ELIZABETH: No, I don't. (4)

PATRICK: Well, the food's always good. (5)

ELIZABETH: Yes, well, I wasn't asking about the food. (6)

ELIZABETH: I'd like to know what was said. (7)

ELIZABETH: Patrick, we grew up together and we've always had a very frank and a very open relationship. (8)

PATRICK: Yes, ma'am. (9)

ELIZABETH: Yes, so... (...) (10) 
It can be observed in the extract that Patrick is trying hard to escape from the dinner issue, for that he flouts one of Grice's Maxims, the Quantity one, for not being informative enough when he says the food's always good. However, the main objective of this paper is to give attention to face as well as politeness strategies, so the maxims are not going to be explored here.

The Queen's next trial is going on record, with negative politeness redress by the utterance in line 7. She is direct in her question, but gives deference to the addressee adding the hedge 'I'd like to know'. Here, the Queen uses negative politeness strategy 1 , be conventionally indirect. Brown \& Levinson (1987, p. 132) explain that when employing this strategy "the speaker is faced with opposing tensions: the desire to give $\mathrm{H}$ an 'out' by being indirect, and the desire to go on record. In this case, it is solved by the compromise of conventional indirectness". The conventional indirectness is given by the application of the hedge, mentioned above. In this case, the utterance in line 7 indicates an on record strategy. However, according to the authors, usually when a speaker uses this kind of technique he/she indicates his/her desire to have gone off record, in other words, to convey the same thing indirectly.

The first clue sent by Patrick that he knows the Queen's wants is the indication that he produces nervous laughter in line (2) and that, if he cooperates with her, he is going to commit an FTA. According to the Politeness theory designed by Brown \& Levinson (1987) this kind of hesitation is also considered a hedge, in this case a kinesic hedge. The authors posit that speakers do not need to utter verbal hedges to indicate that what they are about to say may threaten the hearer's face.

It is of note that the Queen conveys solidarity and indicates that she knows Patrick's wants to protect her face. She also conveys that she takes this into account, so she decides to stablish common ground by uttering line (8). This is explained by strategy 7 . presuppose/raise/assert common ground, when she mentions about their past relationship, we grew up together, and the use of the pronoun we, is an in-group identity marker, by making use of strategy 4. The Queen utters those structures to claim common ground and solidarity to Patrick. It is also interesting to mention that Elizabeth breaks the imposition of the hierarchical implications that exists because of her being a Queen. She has the intention to make their relation close, so he might feel more comfortable to perform the FTA, which is recalling the sentences uttered by Mrs. Kennedy. Therefore, Patrick yields to Elizabeth's claims and agrees to speak.

Despite the Queen's effort to show common ground by using positive politeness strategies to stablish certain level of intimacy, Patrick decides to use a negative politeness strategy addressing Elizabeth by ma'am. This is the formal term people use to address to the Queen on a daily basis. The use of address terms, especially the honorifics, which is the case, according to O'Keeffe, Clancy, \& Adolphs (2019), functions as positive politeness markers (informal terms such as endearments and family terms) and change gradually to more formal terms such as the honorifics. Patrick employs the honorific to bring back the power relation that exists due to Elizabeth's position as a Queen. Thus, he shows that he is going to cooperate with her wants because he is a subordinate, he is obeying an order, so he utters what is in line 9 and satisfies her wants by telling her what he overheard at the dinner as follows:

PATRICK: What I overheard the First Lady say... [stutters] and I should mention, I was several places along the table. (11)

PATRICK: It's possible that I misheard. (12)

ELIZABETH: Yes. (13)

(...)

ELIZABETH: And did she have anything to say about me? (14)

PATRICK: -Oh, Lilibet. (15)

ELIZABETH: Patrick! (16)

PATRICK: I was at the other end of the table, I... But the words I think I overheard were... (17)

According to Brown \& Levinson (1987), when employing negative politeness the speaker uses negative strategies to show deference to the hearer. Hence it is common to use hedges in order to be conventionally indirect in the FTAs performed. In 
the extract above it can be observed that Patrick uses many hedges (What I overheard, I should mention, It's possible that I misheard) meaning that he is not taking full responsibility for the truth of his utterances in lines (11) and (12). This strategy allows the speaker, according to O'Keeffe et al. (2019), to mitigate any threat that might be presented to the hearer's face.

In line (14), Elizabeth uses strategy 7 from positive politeness, she pressuposes her hearer's knowledge of the the issue. In this case, the speaker uses in-group codes to assume that the hearer understands and shares the associations of the code. The code here is the question itself, because they both know that Jackie said something about the Queen. Elizabeth's intention here is so evident that Patrick's next line, (15), almost sounds like a plead. Moreover, he knows that the Queen's face is extremely threatened by that. So he uses the same strategy Elizabeth used to convince him to cooperate with her on satisfying her wants to tell her everything he heard on the dinner. Patrick stablishes common ground, now, he turns back to the use of positive politeness strategies, and makes use of strategy 7 when he addresses the Queen by 'Lilibet' in line (15). "Lilibet" is the Queen's nickname, only family members and very close friends call her by her nickname. Presupposing familiarity in speakerhearer relationship, may therefore soften the threat of FTA according to Brown \& Levinson's theory.

In the subsequent line, (17), Patrick comes back to the use of negative politeness strategies using hedges again, but this time he adds '/ think', to intend that his memory might not be as accurate as it seems. Also, it is a sign that he wants to detach himself from the truth of his following utterances.

It is important to stand out that Patrick witnessed the very indelicate comments stated by Jackie Kennedy about the Queen at Radziwills' dinner. Besides all the deference Patrick shows to Elizabeth whether as a Queen or friend he might also feel the same about the U.S. First Lady for everything she represented at that time. Jackie Kennedy was admired and beloved by everyone for her elegance, beauty and kindness. Jackie's natural behavior even inspired the Queen on an important event she had to attend to during the episode. Therefore, the speech choices made by Patrick during his conversation with Elizabeth also seem an attempt to save Jackie's face and not only the Queen's.

With that said, it is also relevant to point out that Elizabeth invited Patrick for that conversation because she suspected that the words stood by Mrs. Kennedy were not as kind as they should be. The Queen and the First Lady had met some days before and, as far as Elizabeth was concerned, they had got along well, so she was surprised and puzzled over the situation. Furthermore, Elizabeth was interested in Jackie's opinion about her for all the respect and admiration Mrs. Kennedy arouses among people, in fact the Queen seemed to be jealous about people's reaction towards the First Lady presence and image.

In short, the use of positive and negative politeness strategies are clear in the excerpt. In general, it is possible to conclude that the Queen makes more use of bald on record with positive politeness strategies when she is to perform a FTA towards Patrick. In spite of choosing for the most face threatening route, Elizabeth could have opted for an even more imperative tone by ordering Patrick to say everything he knew about Jackie's speech, the way she acts with all her subordinates. Nevertheless, she decided to preserve her friendship and to demonstrate her respect towards her childhood friend using a lighter tone and strategies that stablish common ground. She shows solidarity to the man's effort to save her face and makes use of a few hedges to mitigate the threat to his face. Patrick utters more negative politeness strategies to give deference to his hearer, employs several hedges to soften the FTAs he is about to perform because he complies to the Queen's wants, therefore he prefers to insert the hedges not to be so direct and offensive.

\section{Discussion and conclusion}

As posited by Brown \& Levinson (1987, p. 103) positive "politeness utterances are used as a kind of metaphorical extension of intimacy to imply 
common ground or sharing wants (...)". These are the techniques used by the Queen to convince Patrick to cooperate with her, even when he is not so willing to. It is clear during the analysed dialogue that Patrick makes use of negative politeness techniques. Brown \& Levinson (1987) highlight that speakers may have different motivations to use negative strategies. The authors claim that "the outputs are all forms usefull in general social distancing; they are therefore likely to be used whenever a speaker wants to put a social brake on to the course of this interaction" (Brown \& Levinson, 1987, p. 130).

According to the analysis it could be observed that the Queen goes on record more often than Patrick, better saying, Patrick never goes on record in the extract. He, most of the time, employs negative politeness and uses hedges to mitigate the FTA he is to perform by cooperating with the Queen's wants. It is understandable that Patrick does not go on record because he knows he is talking to the Queen and that, even when she establishes common ground, it is hard for him not to respect the inherent power that exists between them. On the other hand, it seems to be easier for the Queen to go on record; despite her using positive politeness strategies not to sound rude, she is used to being direct to everyone. She knows that her subordinates will do their best to cooperate and to fulfill herwants even when they do not desire to. Furthermore, she knows that they will always save her positive and negative face whenever possible.

Lakoff (1990, p.34) claims that "politeness is a system of interpersonal relations designed to facilitate interaction by minimazing the potential for conflict and confrontation". This claim is clear in the extract above. Patrick uses many politeness strategies to avoid confronting and disagreeing with the Queen's wants. He is vague, he uses verbal and non-verbal hedges, he tries everything he can to avoid desagreeing or saying "no" to the Queen, even when he does not wish to say the truth, so as not to threaten her face. However, Eizabeth's wants are met. She uses her power and positive strategies to achieve her goals, which in the extract is to find out Jackie Kennedy's opinion about her.

Considering Brown \& Levinson's (1987) politeness theory, cooperation and face maintenace are aspects of communication that people who are involved in a conversation tend to respect. The use of politeness strategies are the means to preserve harmony in a community. In the society we live nowadays, in which information and "opinions" are everywhere, specially on the Internet, it is, sometimes, inevitable to avoid moments of conflict and confrontation during interaction. Therefore, it would be very difficult to establish good social relationship without the use of such strategies.

\section{References}

8Flix. FYC. Film and television scripts database (n.d.). Retrieved June 1, 2021, from https://8flix.com/transcripts/tt4786824s2-dialogue-transcripts

Bargiela-Chiappini, F. (2003). Face and politeness: new (insights) for old (concepts). Journal of Pragmatics, 35(10-11), 1453-1469. https://doi.org/10.1016/ S0378-2166(02)00173-X

Brown, P., \& Levinson, S. (1987). Politeness: Some Universals in Language Usage. Cambridge University Press.

Fraser, B. (1990). Perspectives on politeness. Journal of Pragmatics, 14(2), 2019-2036. https://doi.org/10.1016/ 0378-2166(90)go081-N

Goffman, E. (1967). Interaction Ritual. Essays on Face-to-Face Behavior. Anchor Books.

Huang, Y. (2007). Pragmatics. Oxford University Press.

Jansen, F., \& Janssen, D. (2010). Effects of positive politeness strategies in business letters. Journal of Pragmatics, 42(9), 2531-2548. https://doi.org/10.1016/j. pragma.2010.02.013

Lakoff, R. (1990). Talking Power. The Politics of Language. Basic Books.

Leech, G. N. (1983). Principles of pragmatics. Longman.

Leech, G. N. (2003). Towards an anatomy of politeness in communication. International Journal of Pragmatics, 13(3), 101-123. https://doi.org/10.1016/03782166(95)00014-3

O'Keeffe, A., Clancy, B., \& Adolphs, S. (2019). Introducing Pragmatics in Use. Routledge.

Yule, G. (1996). Pragmatics. Oxford University Press. 


\section{Ana Carolina Moura Pompeu}

Mestre em Letras pela Pontifícia Universidade Católica do Rio Grande do Sul (PUCRS), em Porto Alegre, RS, Brasil; doutoranda em Linguística pela Pontifícia Universidade Católica do Rio Grande do Sul (PUCRS), em Porto Alegre, RS, Brasil; professora autônoma de Lingua Inglesa, em Porto Alegre, RS, Brasil.

\section{Mailing address}

Ana Carolina Moura Pompeu

Rua Ney da Gama, 51/603

Morro Santana, 91450-345

Porto Alegre, RS, Brasil

Os textos deste artigo foram revisados pela Poá Comunicação e submetidos para validação do autor antes da publicação. 